\title{
Water quality monitoring of the Pirapó River watershed, Paraná, Brazil
}

\author{
E. C. Bortoletto ${ }^{a *}$, H. A. Silva ${ }^{b}$, C. M. Bonifácio ${ }^{c}$ and C. R. G. Tavares ${ }^{d}$

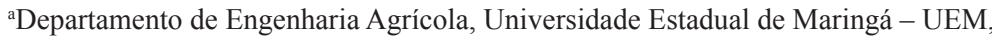 \\ Rodovia PR 482, Km 45, Bloco L025, CEP 87820-000, Cidade Gaúcha, PR, Brazil \\ 'Programa de Pós-graduação em Agronomia, Universidade Estadual de Maringá - UEM, \\ Rodovia PR 482, Km 45, Bloco J45, CEP 87020-900, Maringá, PR, Brazil \\ 'Programa de Pós-graduação em Geografia, Universidade Estadual de Maringá - UEM, \\ Avenida Colombo, 5790, Bloco J12, CEP 87020-900, Maringá, PR, Brazil \\ dDepartamento de Engenharia Química, Universidade Estadual de Maringá - UEM, \\ Avenida Colombo, 5790, Bloco D90, CEP 87020-900, Maringá, PR, Brazil \\ *e-mail: edmilson_bortoletto@yahoo.com.br
}

Received: January 17, 2015 - Accepted: May 20, 2015 - Distributed: November 30, 2015

(With 4 figures)

\begin{abstract}
This study aimed to evaluate the water quality of the Pirapó River watershed in Paraná, Brazil, and identify the critical pollution sites throughout the drainage basin. The water quality was monitored during the period from January 2011 to December 2012. Nine points distributed throughout the main channel of the Pirapó River were sampled for a total of 17 samplings. The water quality was evaluated based on the determination of 14 physical, chemical and microbiological parameters. Analysis of the variables monitored in the Pirapó River watershed using factor analysis/principal components analysis (FA/PCA) indicated the formation of three distinct groups of parameters: water temperature $\left(\mathrm{T}_{\text {water }}\right)$, dissolved oxygen (DO) and a group composed of total suspended solids (TSS), turbidity and nitrite $\left(\mathrm{NO}_{2}^{-}\right)$. The parameters $\mathrm{T}_{\text {water }}$ and DO exhibited a relationship with the seasonality, and the TSS, turbidity, and $\mathrm{NO}_{2}^{-}$levels were correlated with surface runoff caused by rainfall events. Principal component analysis (PCA) of the sampling points enabled the selection of the 10 most important variables from among the 14 evaluated parameters. The results showed that the nitrate $\left(\mathrm{NO}_{3}^{-}\right)$, $\mathrm{NO}_{2}^{-}$, TSS, turbidity and total phosphorous (TP) levels were related to the soil type, and the parameters DO, electrical conductivity (EC), ammoniacal nitrogen $\left(\mathrm{N}_{-} \mathrm{NH}_{3}\right)$ and thermotolerant coliforms (TC) were related to organic matter pollution, with the P5 sampling site being the most critical site. The ordination diagram of the sampling points as a function of the PCA indicated a reduction from 9 to 5 sampling points, indicating the potential for decreasing the costs associated with monitoring.
\end{abstract}

Keywords: monitoring, water quality, Pirapó River, pollution, principal component analysis.

\section{Monitoramento da qualidade da água na bacia hidrográfica do Rio Pirapó, Paraná, Brasil}

\begin{abstract}
Resumo
O objetivo deste trabalho foi avaliar a qualidade da água na bacia hidrográfica do rio Pirapó, Paraná-Brasil, e identificar os pontos críticos de poluição ao longo da bacia. O monitoramento da qualidade da água foi realizado no período de Jan/2011 a Dez/2012, em nove pontos de amostragem distribuídos ao longo do canal principal do rio Pirapó, totalizando 17 coletas. A qualidade da água foi avaliada por meio da determinação de 14 parâmetros físicos, químicos e microbiológicos. A aplicação da Análise Fatorial/Análise das Componentes Principais (AF/ACP) nas variáveis monitoradas na bacia do rio Pirapó indicou a formação de três grupos distintos: Temperatura da água ( $\left.\mathrm{T}_{\text {água }}\right)$, oxigênio dissolvido (OD) e um grupo composto por sólidos suspensos totais (SST), Turbidez e Nitrito $\left(\mathrm{NO}_{2}^{-}\right)$. Os parâmetros $\mathrm{T}_{\text {água }}$ e OD demonstraram relação com a sazonalidade, e os parâmetros SST, Turbidez e $\mathrm{NO}_{2}^{-}$com o escoamento superficial provocado por eventos de precipitação. A análise dos pontos de amostragem por componentes principais (ACP) permitiu selecionar 10 variáveis com maior importância entre as 14 avaliadas. Verificou-se que os parâmetros nitrato $\left(\mathrm{NO}_{3}^{-}\right), \mathrm{NO}_{2}^{-}$, SST, Turbidez e Fósforo Total (FT) estão relacionados ao tipo de solo, e os parâmetros OD, condutividade elétrica $(\mathrm{CE})$, nitrogênio amoniacal $\left(\mathrm{N}-\mathrm{NH}_{3}\right)$ e coliformes termotolerantes $(\mathrm{CT})$ à poluição por matéria orgânica, sendo o ponto P5 de amostragem o trecho mais crítico. O diagrama de ordenação dos pontos de amostragem em função da ACP indicou a redução de 9 para 5 pontos de amostragem, o que implica redução de custos associados ao monitoramento.
\end{abstract}

Palavras-chave: monitoramento, qualidade da água, Rio Pirapó, poluição, análise de componentes principais. 


\section{Introduction}

The gradual decline of surface water quality is directly related to the discharge of municipal sewage and industrial effluents into water bodies, the inadequate disposal of solid wastes and surface runoff from agricultural areas. According to Vega et al. (1998), surface runoff is seasonal and highly affected by climatic conditions and, consequently, has a strong effect on the flow rates and pollutant concentrations in river water.

The expansion of urban areas is one of the main factors responsible for the decrease in surface water quality (Nasir et al., 2011). In rural areas, the quality of surface waters is directly related to the type of land use, landscape modification, the removal of native vegetation for monocropping, the indiscriminant use of pesticides and fertilizers and a lack of human and animal waste treatment (Almeida et al., 2001; Luz, 2009).

Considering the growing influence of anthropogenic factors on water quality, namely, the type of use and occupation of the physical environment and socio-economic activities, it becomes necessary to distinguish the natural characteristics of water from those attributed to human activities (Rebouças et al., 1999).

According to Magalhães Júnior (2000), monitoring systems are essential for the implementation of water management tools because they provide strategic information and a current database regarding the characteristics of each body of water.

Long-term monitoring programs generate large datasets of diverse parameters of water quality. Because the dataset comprises different variables, measured at different scales and units, its interpretation is difficult (França, 2009; Haag and Westrich, 2002). Thus, multivariate statistical methods such as principal component analysis (PCA) have been successfully used in the interpretation of water quality monitoring data (Bhardwaj et al., 2010; Helena et al., 2000; Ouyang, 2005; Simeonov et al., 2003; Singh et al., 2004).

PCA seeks to transform the original set of observed variables into a new set of variables, called principal components. The main characteristic of these components, in addition to orthogonality, is that they are obtained in descending order of maximum variance (Guedes et al., 2012).

This study aimed to evaluate the water quality in the Pirapó River watershed in Paraná, Brazil, and identify the critical pollution sites throughout the drainage basin by applying factor analysis to the variables and PCA for the sampling points.

\section{Material and Methods}

\subsection{Water quality monitoring}

This study was conducted in the Pirapó River watershed (Figure 1) located in the northern region of the state of Paraná. Macro-location was used to define nine sampling

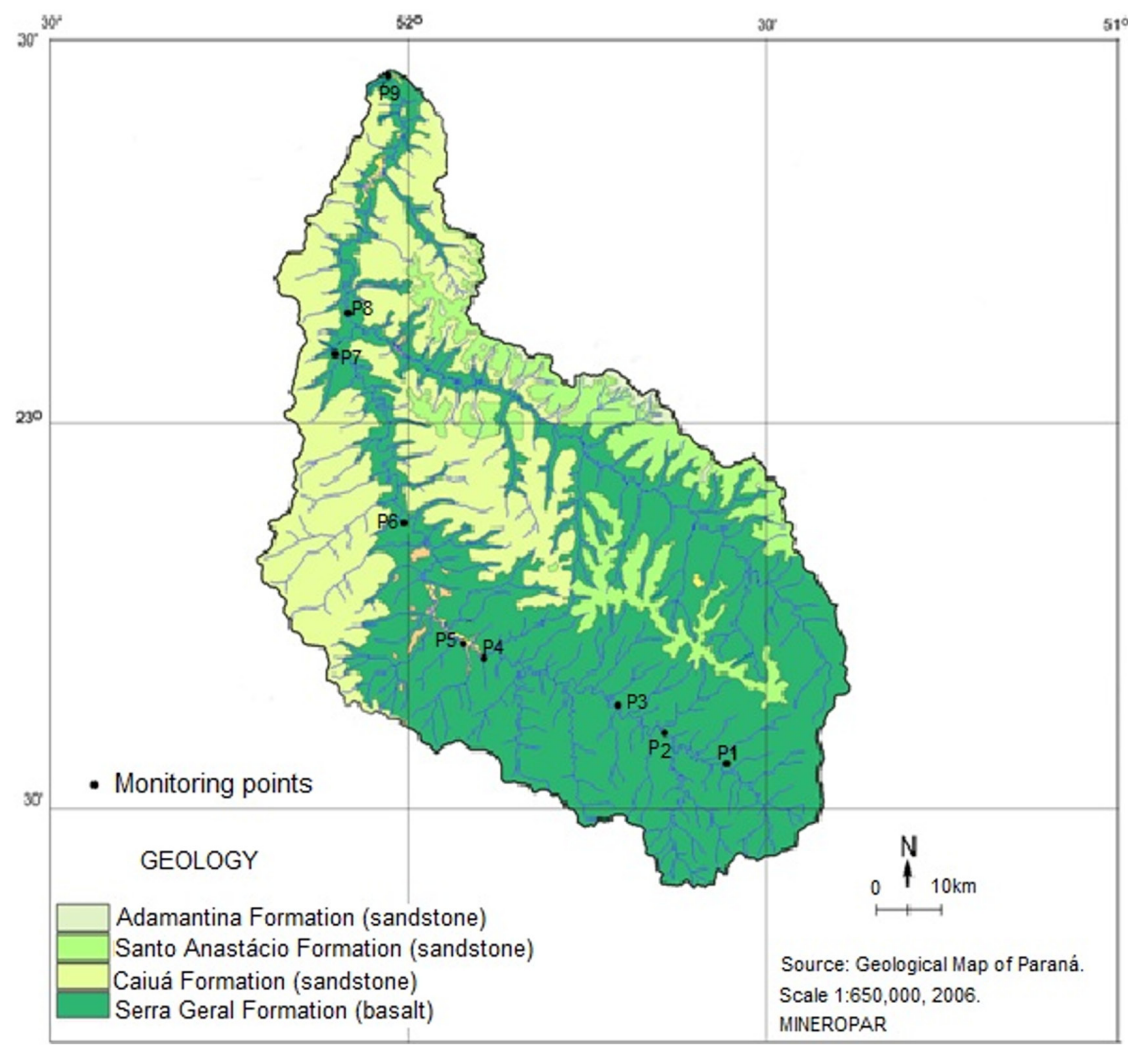

Figure 1. Pirapó River Watershed. 
points distributed along the main channel of the Pirapó River (Figure 1, Table 1). The first point was located close to the river source, and the last point was near the mouth of the Paranapanema River. Points P1 to P5 were located in the Serra Geral Formation (basalt), and points P6 to P9 were in areas consisting of soil from the Caiuá and Santo Anastácio Formations (sandstone), as shown in Figure 1.

Regarding the water pollution identified at point P5, one of the factors affecting this site was the discharge of sewage from an ETE into the Maringá stream, which is a tributary of the stretch represented by point P5. It is likely that even after sewage treatment, the discharged waste contributes significantly to the reduced water quality observed at this site.

The surface water samples were collected from bridges using the composite method. After collection, the samples were transferred into polyethylene terephthalate (PET) containers and glass flasks (previously washed) and acidified with sulfuric or nitric acid according to Clescerl et al. (1998). For the analysis of microbiological parameters, the samples were transferred into previously sterilized Schott bottles. After sampling and storage, the samples were kept refrigerated in Styrofoam boxes with ice for preservation and then brought to the Laboratory of Environmental Management, Control and Preservation (Laboratório de Gestão, Controle e Preservação Ambiental - LGCPA) of the Department of Chemical Engineering (Departamento de Engenharia Química - DEQ) of the State University of Maringá (Universidade Estadual de Maringá - UEM) for analysis.

Water temperature $\left(\mathrm{T}_{\text {water }}\right), \mathrm{pH}$, dissolved oxygen (DO) and electrical conductivity (EC) were determined using a multi-parameter probe $(\mathrm{HACH})$ on site. Turbidity was determined using an APTO 1000II turbidimeter. The true color, ammoniacal nitrogen $\left(\mathrm{N}-\mathrm{NH}_{3}\right)$, nitrite $\left(\mathrm{NO}_{2}^{-}\right)$, nitrate $\left(\mathrm{NO}_{3}^{-}\right)$and total phosphorous (TF) levels were measured with a HACH DR/2010 portable data-logging spectrophotometer. Biochemical oxygen demand (BOD) was measured with a HACH BODTrak ${ }^{\mathrm{TM}}$ II device. Total suspended solids (TSS) and total solids (TS) were determined according to the methodology described by the American Public Health Association - Standard Methods for the Examination of Water and Wastewater (Clescerl, 1998). Thermotolerant coliforms (TC) were measured using 3M Petrifilm plates for fecal coliform counts according to the Association of Official Analytical Chemists (AOAC, 2005) 991.14 method and were expressed as colony forming units per $100 \mathrm{~mL}$ of sample (CFU $100 \mathrm{~mL}^{-1}$ ).

To evaluate the quality of the surface waters of the Pirapó River, 17 sampling events were performed during the period from January 2011 to December 2012 (Table 2).

Cumulative precipitation data for the 48 hours prior to sample collection, obtained from SUDERHSA weather monitoring stations, were used to assess the effect of rainfall on the physicochemical and microbiological parameters. Rainfall data from 5 weather stations (Arapongas, Astorga, Maringá, Colorado, Jardim Olinda) located along the catchment area of the basin were used to obtain the mean precipitation value for the Pirapó River watershed. The mean values of precipitation $(\mathrm{mm})$ for each sampling are shown in Table 2 .

Table 2 shows that rainfall occurred prior to sample collection only for samplings S1, S3, S8, S10 and S16. The highest mean precipitation was observed for the S3 sampling, where $78.6 \mathrm{~mm}$ had accumulated in the 48 hours prior to collection.

\subsection{Statistical analysis}

The parameters measured for the water quality monitoring of the Pirapó River were evaluated using factor analysis with extraction by principal component analysis (FA/PCA) to identify the relationships between the variables that affect water quality. The water quality data were standardized, and a correlation matrix was constructed. For the orthogonalization of the factors, the normalized varimax rotation was applied (Helena et al., 2000; Aprile and Farias, 2001; Kuppusamy and Giridhar, 2006).

To evaluate and correlate the fixed sampling points where the variables were measured, the sampling points were subjected to an exploratory analysis by principal components using the mean values. The data were also standardized due to the different scales adopted for each predictor variable (Cruz et al., 2012; Guedes et al., 2012). All analyses were conducted using Statistica ${ }^{\circledR}$ software version 7.0

Table 1. Locations of the sampling points.

\begin{tabular}{|c|c|c|c|c|}
\hline Points & Location & Latitude & Longitude & Altitude (m) \\
\hline $\mathrm{P} 1$ & Downstream of the Abutre confluence & $23^{\circ} 26^{\prime} 586^{\prime \prime}$ & $51^{\circ} 33^{\prime} 186^{\prime \prime}$ & 553 \\
\hline $\mathrm{P} 2$ & Upstream of Vitória stream & $23^{\circ} 24^{\prime} 018^{\prime \prime}$ & $51^{\circ} 38^{\prime} 455^{\prime}$ & 454 \\
\hline P3 & Downstream of Araçu stream & $23^{\circ} 21^{\prime} 959^{\prime}$ & $51^{\circ} 42^{\prime} 510^{\prime \prime}$ & 411 \\
\hline P4 & Downstream of Guarujá stream & $23^{\circ} 18^{\prime} 257^{\prime}$ & $51^{\circ} 53^{\prime} 595^{\prime}$ & 393 \\
\hline P5 & Downstream of Maringá stream & $23^{\circ} 17^{\prime} 192^{\prime \prime}$ & $51^{\circ} 55^{\prime} 416^{\prime \prime}$ & 394 \\
\hline P6 & Upstream of Flórida stream & $23^{\circ} 07^{\prime} 844^{\prime \prime}$ & $52^{\circ} 00^{\prime} 329^{\prime \prime}$ & 377 \\
\hline P7 & Upstream of Bandeirantes do Norte River & $22^{\circ} 54^{\prime} 637^{\prime \prime}$ & $52^{\circ} 06^{\prime} 088^{\prime \prime}$ & 336 \\
\hline P8 & Downstream of Bandeirantes do Norte River & $22^{\circ} 54^{\prime} 431^{\prime \prime}$ & $52^{\circ} 04^{\prime} 642^{\prime}$ & 309 \\
\hline P9 & Downstream of the Pau d'Alho confluence & $22^{\circ} 32^{\prime} 900^{\prime \prime}$ & $52^{\circ} 01^{\prime} 722^{\prime}$ & 269 \\
\hline
\end{tabular}




\section{Results and Discussion}

\subsection{Water quality of the river}

\subsubsection{Correlation matrix}

The correlation matrix [R] of the studied variables in the Pirapó River watershed is shown in Table 3. According to Cohen (1988), correlations greater than 0.70 can be considered strong. The analysis of the obtained correlations showed that the majority of the variables exhibited moderate to strong associations, with many correlations being significant according to the T-test at $5 \%$ probability. This relationship is required when performing analyses based on a covariance matrix (Cruz et al., 2012).

3.1.2. Evaluation of the monitored variables by factor analysis using principal components (FA/PCA)

The results of the factor analysis of the monitored variables in the Pirapó River watershed are shown in Table 4. These components express the relationships between factors and variables and enable the identification of the most closely related variables in each component. In this sense, higher values of these factor loadings indicate a greater significance of the variables in each factor.

The two components (PS1 and PS2) explained 60.85\% of the total variance of the system (Table 4), with Factor 1 explaining the majority of this variation $(42.52 \%)$. Variables with the largest eigenvalues in Factor 1, such as turbidity, TSS and nitrite, were considered the most important parameters in the system and were thus essential for the water quality evaluation. Regarding Factor $2, \mathrm{~T}_{\text {water }}$ and DO were the most informative variables. These variables were the most significant in both factors and were thus the most significant in the definition of the studied water quality.
Figure 2 shows the relationship between factors and variables in the two components, in which the representativeness and influence of the characteristics are greater when further from the origin relative to the two axes. The formation of 3 distinct groups is observed: $\mathrm{T}_{\text {water, }}$, DO and a group composed of TSS, turbidity and nitrite.

All other variables exhibited low representativeness, as they were located close to the origin. These variables are shown to be of minor importance for the evaluation of the system due to their less informative nature.

The water temperature was related to the seasonality, varying according to the seasons of the year. This parameter ranged between $16.2^{\circ} \mathrm{C}$ and $31.7^{\circ} \mathrm{C}$, recorded during samplings $\mathrm{S} 4$ and $\mathrm{S} 17$, respectively.

The dissolved oxygen (DO) levels showed an inverse relationship with $\mathrm{T}_{\text {water }}$, indicating an influence of the seasonality on the solubility of oxygen. In all analyzed samples, the concentrations of DO were above the minimum value stipulated by Brazilian legislation, which is $5 \mathrm{mgL}^{-1}$. Thus, during the evaluation period, DO values that could jeopardize the preservation of aquatic life were not observed.

Regarding the TSS, the largest values were observed during the S3 sampling and were related to the rainfall that occurred prior to the collection period (Table 2). An increase in rainfall promotes a greater input of suspended material, resulting from surface runoff of soil and erosive processes in the riverbed.

The turbidity values varied between 1.8 and 656 NTU, recorded during samplings $\mathrm{S} 5$ and $\mathrm{S} 3$, respectively. In the S3 sampling, all samples exhibited turbidity values greater than the limit stipulated by Brazilian legislation (Resolution CONAMA \# 357/2005 - Brasil, 2005), i.e., 100 NTU. The turbidity results were also related to the cumulative precipitation in the days prior to collection

Table 2. Samplings and respective mean precipitation $(\mathrm{mm})$ in the Pirapó River watershed accumulated in the 48 hours prior to collection.

\begin{tabular}{cccccccc}
\hline Sampling & $\begin{array}{c}\text { Date of } \\
\text { Collection }\end{array}$ & Arapongas & Astorga & Maringá & Colorado & $\begin{array}{c}\text { Jardim } \\
\text { Olinda }\end{array}$ & $\begin{array}{c}\text { Mean } \\
\text { precipitation }\end{array}$ \\
\hline S1 & $12 / 01 / 2011$ & 10.9 & 23.7 & 26.2 & 0 & 9.1 & 14.0 \\
S2 & $10 / 03 / 2011$ & 0 & 0 & 0 & 0 & 0 & 0 \\
S3 & $14 / 04 / 2011$ & 84.7 & 86.6 & 51.9 & 79.8 & 90.1 & 78.6 \\
S4 & $19 / 05 / 2011$ & 0 & 0 & 0 & 0 & 0 & 0 \\
S5 & $26 / 07 / 2011$ & 0 & 0 & 0 & 0 & 0 & 0 \\
S6 & $05 / 09 / 2011$ & 0 & 0 & 0 & 0 & 0 & 0 \\
S7 & $03 / 11 / 2011$ & 0 & 0 & 0 & 0 & 0 & 0 \\
S8 & $08 / 12 / 2011$ & 7.3 & 9.5 & 3.8 & 5.3 & 22 & 9.6 \\
S9 & $31 / 01 / 2012$ & 0 & 0 & 0 & 0 & 0 & 0 \\
S10 & $11 / 04 / 2012$ & 9.8 & 9.8 & 3.2 & 0 & 11.5 & 6.9 \\
S11 & $22 / 05 / 2012$ & 0 & 0 & 0 & 0 & 0 & 0 \\
S12 & $28 / 06 / 2012$ & 0 & 0 & 0 & 0 & 0 & 0 \\
S13 & $02 / 08 / 2012$ & 0 & 0 & 0 & 0 & 0 & 0 \\
S14 & $11 / 09 / 2012$ & 0 & 0 & 0 & 0 & 0 & 0 \\
S15 & $09 / 10 / 2012$ & 0 & 0 & 0 & 0 & 0 & 0 \\
S16 & $12 / 11 / 2012$ & 15.3 & 8 & 23.8 & 0 & 10 & 14.27 \\
S17 & $11 / 12 / 2012$ & 0 & 0 & 0 & 0 & 0 & 0 \\
\hline
\end{tabular}


Bortoletto, E.C. et al.

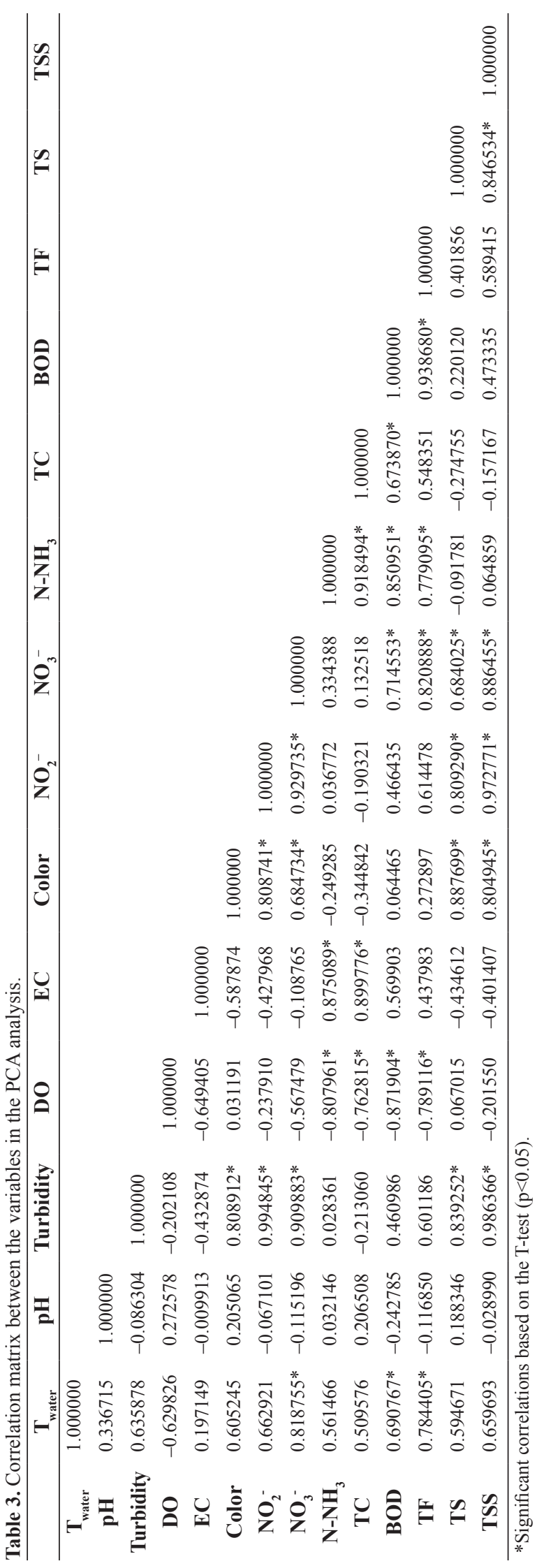


(Table 2) because a greater input of suspended solids promotes increased turbidity.

With the exception of point 4 in the S17 sampling, all sampling points exhibited nitrite values above those recommended by the legislation $\left(1 \mathrm{mg} \mathrm{L}^{-1} \mathrm{~N}\right)$, varying between 1.5 and $138.5 \mathrm{mg} \mathrm{L}^{-1}$. High nitrite values indicate the presence of effluents of domestic and industrial origin in addition to animal excrement and fertilizers originating from agricultural areas. During the S3 sampling, the samples exhibited much higher values for each site compared to

Table 4. Results of the FA/PCA for the monitored variables in the Pirapó River watershed.

\begin{tabular}{ccccc}
\hline Variables & Factor 1 & Factor 2 & Loadings PS1 & Loadings PC2 \\
\hline $\mathrm{T}_{\text {water }}$ & 0.112427 & $1.041704^{*}$ & -0.028591 & $0.963255^{*}$ \\
$\mathrm{pH}$ & 0.046150 & -0.086511 & -0.083906 & 0.021133 \\
Turbidity & $0.519820^{*}$ & 0.076246 & $0.943999^{*}$ & 0.007288 \\
$\mathrm{DO}$ & -0.030292 & $-0.256418^{*}$ & -0.062074 & $-0.712241^{*}$ \\
$\mathrm{EC}$ & 0.220120 & -0.140120 & -0.268487 & 0.153083 \\
True color & -0.109771 & -0.169015 & 0.553159 & 0.273235 \\
Nitrite & $0.482803^{*}$ & 0.073322 & $0.926041^{*}$ & -0.004488 \\
Nitrate & -0.154277 & -0.131453 & 0.424731 & 0.334702 \\
$\mathrm{~N}_{\text {ammoniacal }}$ & -0.090561 & -0.078128 & 0.528942 & 0.207797 \\
$\mathrm{TC}$ & -0.208881 & 0.034835 & 0.329440 & 0.010567 \\
BOD & -0.042199 & 0.033796 & 0.151566 & 0.038204 \\
$\mathrm{TF}$ & -0.147895 & -0.201871 & 0.284159 & 0.269895 \\
$\mathrm{TS}$ & -0.166225 & -0.030082 & 0.629222 & 0.088522 \\
TSS & $0.545198^{*}$ & 0.082911 & $0.958325 *$ & -0.013328 \\
Eigenvalues & $\mathbf{5 . 9 5 2 6 1 9}$ & $\mathbf{2 . 5 6 6 7 0 1}$ & & \\
Cumulative Variance (\%) & $\mathbf{4 2 . 5 1 8 7 0 3 7 2}$ & $\mathbf{6 0 . 8 5 2 2 8 2 2 3}$ & & \\
\hline
\end{tabular}

*Significant variables.

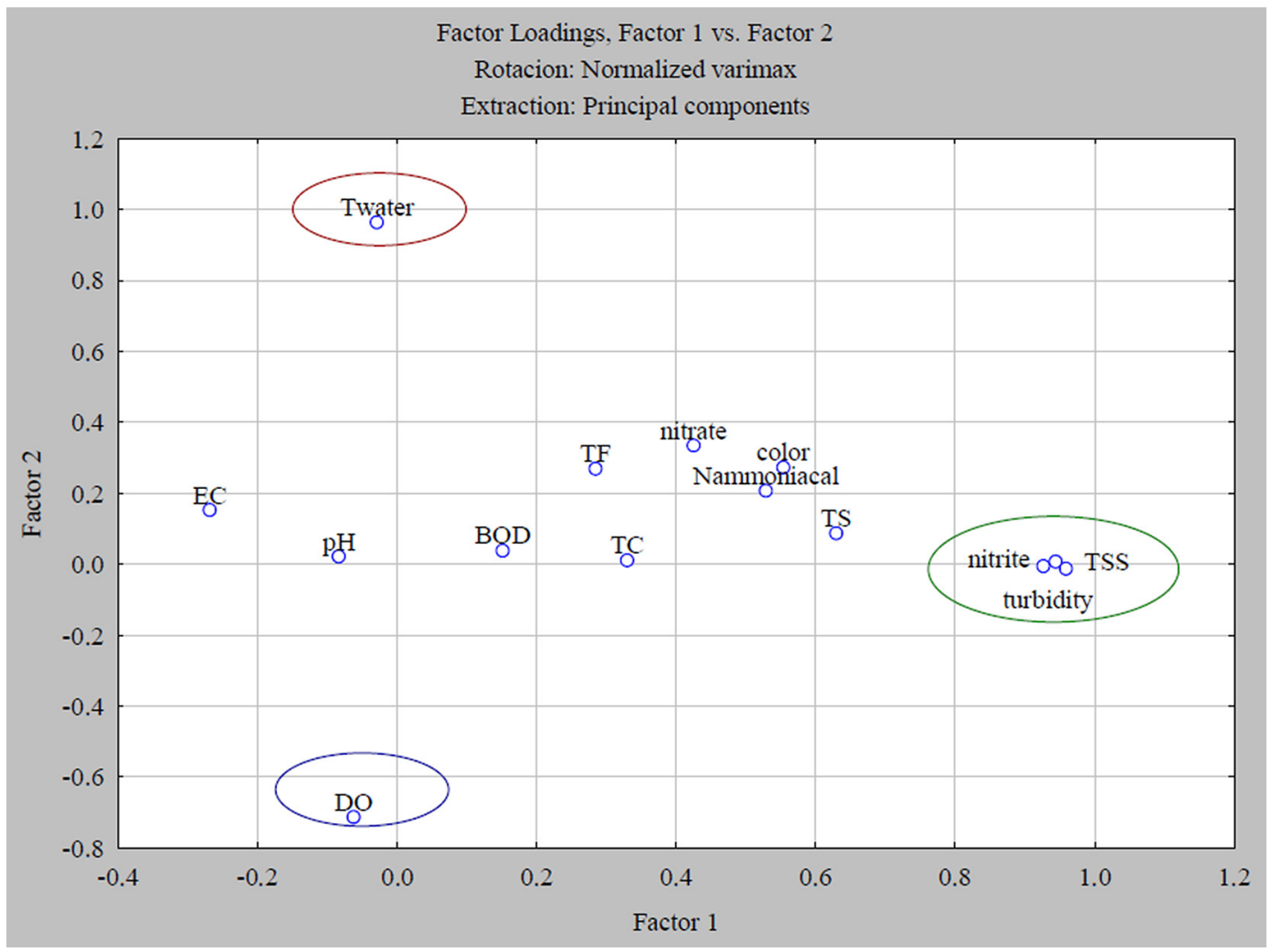

Figure 2. Relationship between factors and variables in the FA/PCA analysis. 
the results obtained during the other samplings, showing a direct relationship between nitrite levels and surface runoff.

Thus, the variation in the water quality of the Pirapó River watershed at the sampling points throughout the monitoring period exhibited a relationship with seasonality for the parameters $\mathrm{T}_{\text {water }}$ and DO and a relationship with rainfall events for the parameters TSS, turbidity and nitrite.

\subsubsection{Analysis of the sampling points using principal component analysis (PCA)}

The factor loading matrix of the water quality variables as a function of the sampling points is shown in Table 5 . For this analysis, the standardized mean of the variables was used, assuming that at least $70 \%$ of the total variance was explained by components 1 and 2 .

Variables of less importance do not vary between the sampling points or are redundant because they are correlated. The most important variables should be maintained and carefully sampled, as they represent the fundamental basis for the evaluation of water quality and are sufficiently diverse to represent the most important aspects of the system.

Table 5 shows that component 1 was mainly influenced by the variables $\mathrm{T}_{\text {water }}$, TSS, turbidity, $\mathrm{NO}_{2}^{-}, \mathrm{NO}_{3}^{-}$and $\mathrm{TF}$, whereas component 2 had a strong influence of DO, $\mathrm{EC}, \mathrm{N}_{-} \mathrm{NH}_{3}$ and TC. These 10 variables exhibit greater relevance among the 14 variables evaluated, providing the fundamental structure of the system and allowing for the grouping of sampling points as a function of the behavior relative to these variables.

The variation in water temperature between the sampling points is associated with the collection time and is proportional to the variation in air temperature throughout the day. No behavior indicative of significant alterations due to anthropogenic activities was observed.

Regarding the TSS, the results demonstrate that the sampling points located in sandstone soils (P6, P7, P8 and P9) exhibited larger values, indicating the greater vulnerability of this type of soil to erosive processes compared to basalt area As turbidity is associated with suspended solids, the largest values of this parameter were also found at sites located in sandstone soils.

With the exception of point 4 during the S17 sampling, all sites exhibited nitrite values above those recommended by the legislation $\left(1 \mathrm{mg} \mathrm{L}^{-1} \mathrm{~N}\right)$, varying between 1.5 and $138.5 \mathrm{mg} \mathrm{L}^{-1}$. During the S3 sampling (i.e., following a high precipitation event), the samples displayed values much higher for each sampling point than those obtained from the other samplings. In general, the points located in sandstone soils exhibited larger nitrite values. High concentrations of nitrite indicate the presence of domestic and industrial effluents as well as animal excrement and show a direct relationship with the use of agricultural fertilizers that reach bodies of water via surface runoff.

Regarding the concentration of nitrate in the water, during samplings S1, S3, S5, S15, S16 and S17, all samples exhibited values above those stipulated by the legislation $\left(10 \mathrm{mg} \mathrm{L}^{-1}\right)$. The presence of nitrate in a body of water is
Table 5. Factor loading matrix of the water quality variables in the two selected principal components.

\begin{tabular}{ccc}
\hline Component & $\mathbf{1}$ & $\mathbf{2}$ \\
\hline Eigenvalue & 7.026795 & 4.843601 \\
Cumulative & 50.1914 & 84.7885 \\
Variance \% & & \\
\hline Variables & \multicolumn{2}{c}{ Coefficients (eigenvectors) } \\
\hline $\mathrm{T}_{\text {water }}$ & $-0.126027^{*}$ & -0.036799 \\
$\mathrm{pH}$ & 0.001990 & 0.014141 \\
Turbidity & $-0.125304^{*}$ & 0.090732 \\
$\mathrm{DO}^{*}$ & 0.083740 & $0.146783^{*}$ \\
$\mathrm{EC}$ & -0.001855 & $-0.201398^{*}$ \\
True Color & -0.095461 & 0.131778 \\
$\mathrm{NO}_{2}^{-}$ & $-0.126436^{*}$ & 0.086855 \\
$\mathrm{NO}_{3}^{-}$ & $-0.138753^{*}$ & 0.018492 \\
$\mathrm{~N}^{-} \mathrm{NH}_{3}$ & -0.065190 & $-0.178026^{*}$ \\
$\mathrm{TC}^{*}$ & -0.036179 & $-0.188540^{*}$ \\
$\mathrm{BOD}^{*}$ & -0.109851 & -0.120382 \\
$\mathrm{TF}^{*}$ & $-0.124113^{*}$ & -0.087152 \\
$\mathrm{TS}^{*}$ & -0.102820 & 0.112682 \\
$\mathrm{TSS}^{*}$ & $-0.125521^{*}$ & 0.085375 \\
\hline
\end{tabular}

*Selected variables.

an indicator of remote pollution related to the endproduct of nitrification. Additionally, high nitrate values during periods of rainfall indicate the leaching of nitrate present in agricultural compounds and animal excrement. It is also noteworthy that the sampling points located in sandstone sites showed higher nitrate values overall.

The concentration of phosphorous varied between 0.05 and $1.09 \mathrm{mg} . \mathrm{L}^{-1}$, and most of the samples exhibited values greater than those established in the legislation, which is $0.1 \mathrm{mg} \mathrm{L}^{-1}$. Those values above the permitted level may be related to extensive agricultural activities in the region and the release of domestic and industrial sewage.

Rainfall promoted an increase in the concentration of total phosphorous, indicative of fertilizer input due to surface runoff. However, there was no direct relationship between the total phosphorous level and the rainfall intensity; e.g., the values from the S3 sampling (highest precipitation) were lower than the values from $\mathrm{S}$, which had a much lower precipitation value. A direct proportion could not be obtained because the release of domestic and industrial sewage contributed significantly to the input of phosphorous to the river system. The results from the S3 sampling indicate that the points located in sandstone soil exhibited significantly greater phosphorous values than points located in basalt soil. During the S1 and S17 samplings, the points located in sandstone soil also exhibited high phosphorous values; however, points P4 and P5, which were located in a region of basalt soil, exhibited values similar to those of the sandstone sites, indicating that the release of domestic and industrial sewage substantially influenced the concentration of phosphorous in that stretch of the river. 
Thus, the parameters nitrate, nitrite, TSS, turbidity and TF were found to be related to soil fragility, with sampling points located in sandstone soil exhibiting a larger effect on water quality that was intensified by rainfall events.

The second principal component was strongly influenced by the variables $\mathrm{DO}, \mathrm{EC}, \mathrm{N}-\mathrm{NH}_{3}$ and TC.

Sampling points P5 and P6 exhibited lower values of DO throughout the study period. Point P5 was located downstream of the entry of a tributary of the Pirapó River that receives organic effluents from a waste treatment station (estações de tratamento de esgoto - ETE) of the city of Maringá. This input of organic material likely contributes to the alteration of water quality in this area. All analyzed samples exhibited a concentration of DO greater than the minimum value stipulated by the Brazilian legislation, $5 \mathrm{mgL}^{-1}$.

The minimum and maximum electrical conductivity values were $71.9 \mu \mathrm{S} \mathrm{cm}^{-1}$ and $233.0 \mu \mathrm{S} \mathrm{cm}^{-1}$, respectively. According to CETESB (2009), electrical conductivity values of water greater than $100 \mu \mathrm{S} \mathrm{cm} \mathrm{cm}^{-1}$ are indicative of impacted environments. The stretch represented by point P5 exhibited conductivity values greater than those of all the other stretches, including the maximum value. This observation may be associated with a tributary that receives constant discharge of organic matter as well as effluents from a local industry.
The concentrations of ammoniacal nitrogen during the study period varied from 0.06 to $3.97 \mathrm{mg} \mathrm{L}^{-1}$, and the S3 samples exhibited values that were generally higher for this parameter. The stretch represented by point P5 exhibited the largest number of samples with ammoniacal nitrogen values above those permitted by law. These values are also related to the input of organic discharge from the ETE of Maringá.

For the TC variable, no values of thermotolerant coliforms above the limits set by law were detected during samplings S4, S5, S6, S7, S9, S11, S13 and S14. During the S3 sampling, with the exception of point $\mathrm{P} 1$, all samples exhibited TC values greater than those permitted by law $(1,000 \mathrm{CFU} / 100 \mathrm{~mL})$. The largest value $(13,900 \mathrm{CFU} / 100 \mathrm{~mL})$ was observed at the $\mathrm{P} 5$ sampling point, located downstream of a tributary that receives domestic discharge from an ETE. This variable was not found to be related to the greater susceptibility of sandstone soil.

Thus, the second principal component was related to pollution by organic matter, and the P5 sampling point was the most critical site; in addition, site P5 affects point P6, located downstream.

The dispersion diagram of the sampling points as a function of the two principal components obtained for the Pirapó River watershed is shown in Figures 3 and 4. The proximity of the points in the plot indicates similar

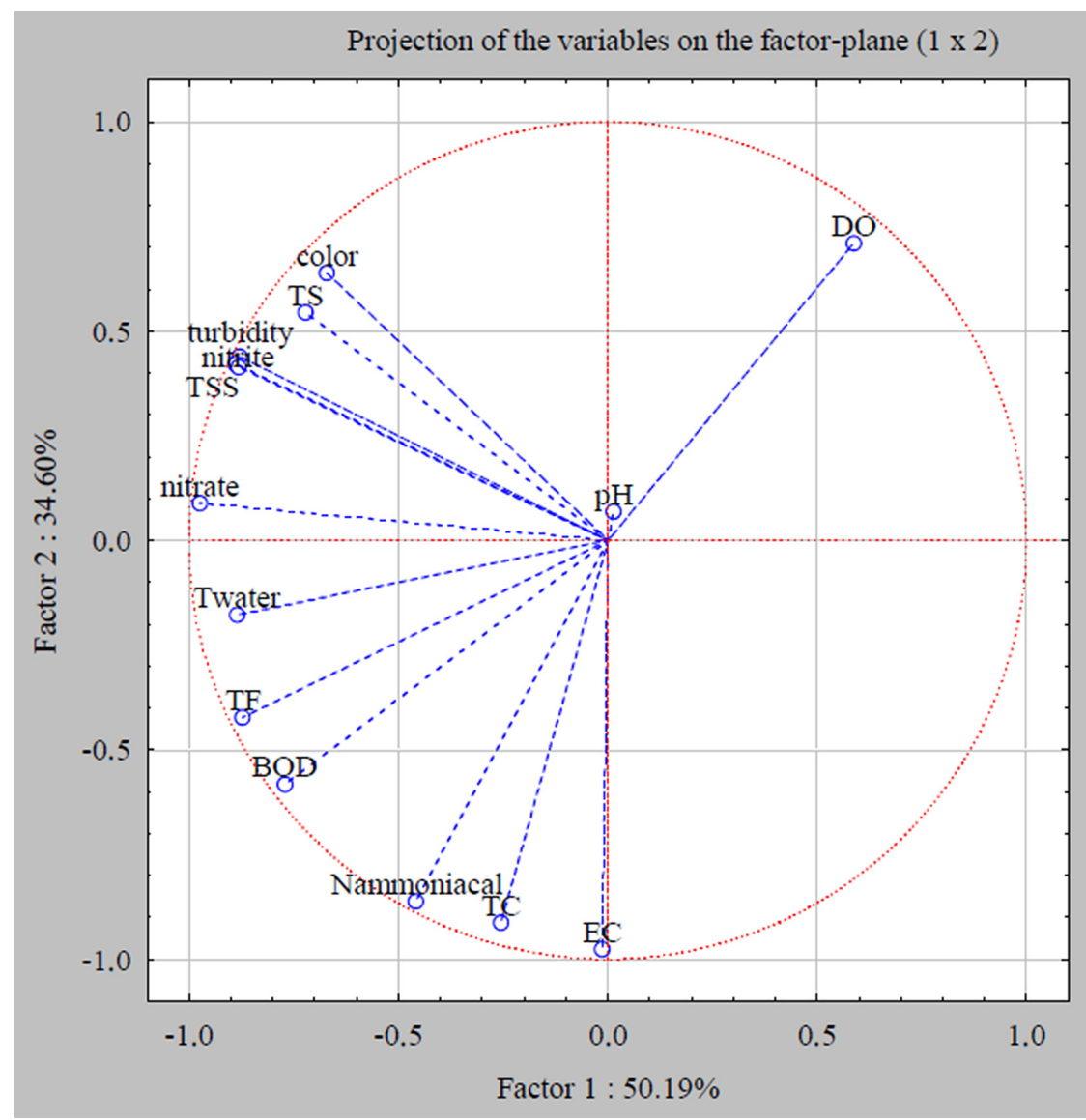

Figure 3. Principal component analysis of the sampling points - correlation circle. 


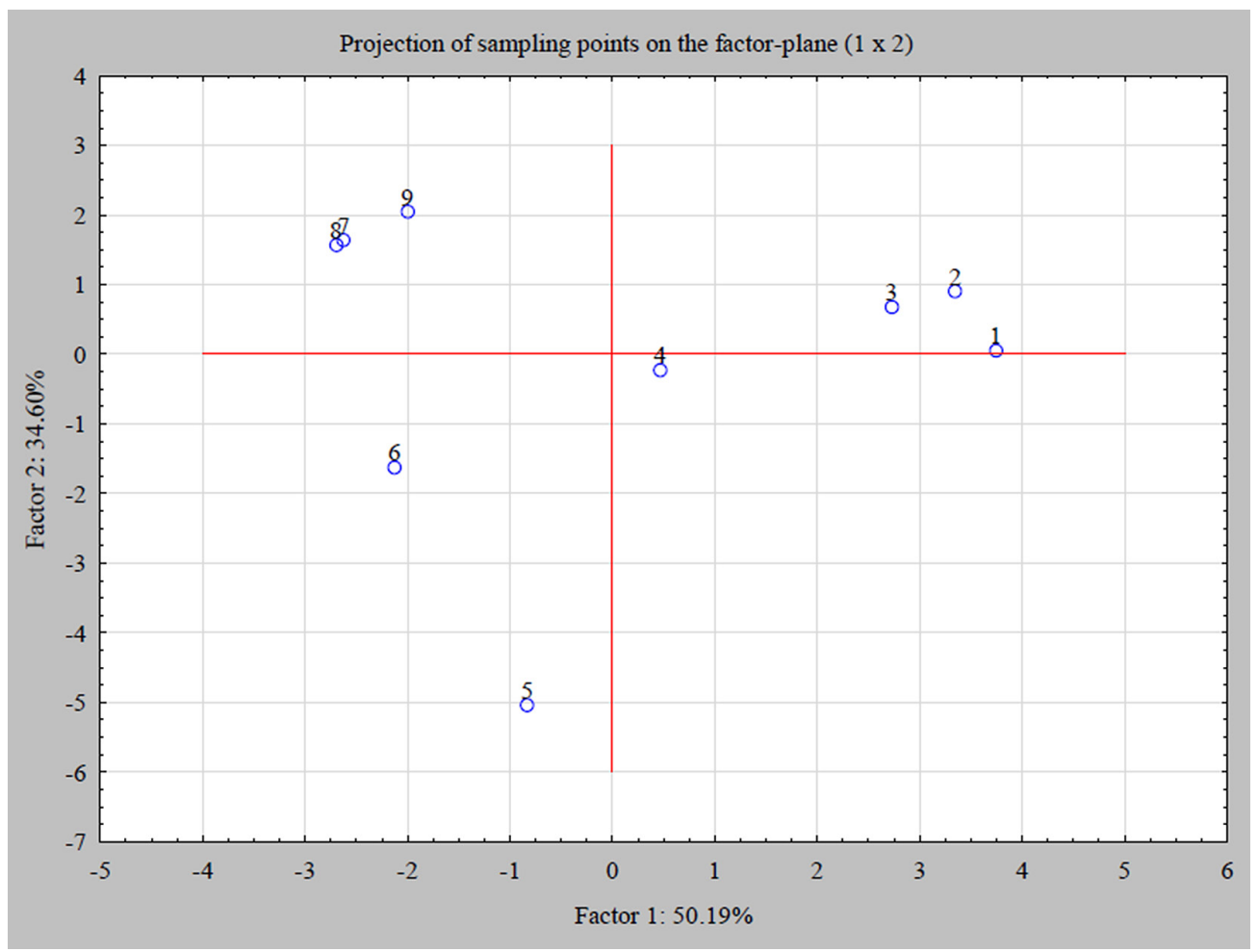

Figure 4. Principal components analysis of the sampling sites - distribution of the ordination diagram of sampling points as a function of the principal components for the Pirapó River watershed.

behavior regarding the key variables of each component, and therefore, they can be reduced to one sampling point per group. Thus, the points $\mathrm{P} 1, \mathrm{P} 2$ and $\mathrm{P} 3$ could be reduced to only one sampling point, as can points $\mathrm{P} 7, \mathrm{P} 8$ and $\mathrm{P} 9$. Thus, the 9 sampling points could be reduced to 5 without compromising the water quality evaluation system.

In the correlation circle (Figure 3), turbidity, TSS, nitrite, nitrate, $\mathrm{N}$-ammoniacal and $\mathrm{EC}$ emerged as the best represented variables. Turbidity, TSS and nitrite were strongly positively correlated with each other and were closely related to the variable nitrate. However, there was a weak or negative correlation with $\mathrm{DO}, \mathrm{N}$-ammoniacal and EC. The variables BOD, TF and $\mathrm{N}$-ammoniacal were positively correlated with one another and showed a strong negative correlation with DO.

The behavior of the DO was extremely relevant for the formation of a group combining the sampling points P1, P2 and P3, as shown in Figure 4, whereas the group including points $\mathrm{P} 7, \mathrm{P} 8$ and $\mathrm{P} 9$ was primarily influenced by the variables turbidity, TSS, nitrite and nitrate. Very little can be inferred regarding the influence of the other variables on the observed arrangement.

\section{Conclusion}

The application of FA/PCA to the monitored variables of the Pirapó River watershed indicated the formation of three distinct groups: $\mathrm{T}_{\text {water }}$ DO and a group composed of TSS, turbidity and nitrite. The parameters $\mathrm{T}_{\text {water }}$ and
DO showed a relationship with the seasonality, and the parameters TSS, turbidity and nitrite were correlated with the surface runoff resulting from rainfall events.

The analysis of sampling points using PCA allowed for the selection of the 10 most important variables among the 14 evaluated parameters. The parameters nitrate, nitrite, TSS, turbidity and TF showed the highest values in sampling points located in sandstone soil, which was associated with the greater instability of this soil compared to the basalt soil. The second principal component was related to pollution by organic matter, which was represented by the

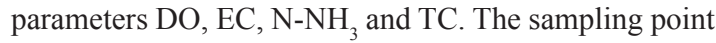
P5 was identified as the most critical site, affecting the quality of the water collected at the downstream point $\mathrm{P} 6$.

The ordination diagram of sampling points using PCA indicated the potential to reduce the number of sampling points from 9 to 5, which would have a direct effect on monitoring costs.

\section{Acknowledgements}

The authors thank the Brazilian Innovation Agency (Financiadora de Estudos e Projetos - FINEP) and the Brazilian Federal Agency for Support and Evaluation of Graduate Education (Coordenação de Aperfeiçoamento de Pessoal de Nível Superior - CAPES) for providing financial support of this study. 


\section{References}

ALMEIDA, S.G., PETERSEN, P. and CORDEIRO, A., 2001. Crise socioambiental e conversão ecológica da agricultura brasileira: subsidios à formação de diretrizes ambientais para o desenvolvimento agrícola. Rio de Janeiro: AS-PTA Assessoria e Serviços a Projetos em Agricultura Alternativa.

APRILE, F.M. and FARIAS, V.P., 2001. Avaliação da qualidade da água da bacia do rio Goiana, Pernambuco - Brasil. Bioikos, vol. 15 , no. 2 , pp. 109-114.

ASSOCIATION OF OFFICIAL ANALYTICAL CHEMISTS AOAC, 2005. Official Methods of Analysis. 18th ed. Gaitherburg: AOAC

BHARDWAJ, V., SINGH, D.S. and SINGH, A.K., 2010. Water quality of the Chhoti Gandak River using principal component analysis, Ganga Plain, India. Journal of Earth System Science, vol. 119, no. 1, pp. 117-127. http://dx.doi.org/10.1007/s12040010-0007-8.

BRASIL. Ministério do Meio Ambiente - MMA. Conselho Nacional do Meio Ambiente - COMAMA, 2005. Resolução $n^{\circ}$ 357, de 17 de março de 2005. Dispõe sobre a classificação dos corpos de água e diretrizes ambientais para o seu enquadramento, bem como estabelece as condições e padrões de lançamento de efluentes, e dá outras providências. Diário Oficial da União, Brasília, 18 mar.

CLESCERL, L.S., GREENBERG, A.E. and EATON, A.D. eds., 1998. Standard methods for the examination of water and wastewater. 20th ed. Washington: American Public Health Association.

COHEN, J., 1988. Statistical power analysis for the behavioral sciences. Hillsdale: Erlbaum.

COMPANHIA AMBIENTAL DO ESTADO DE SÃO PAULO - CETESB, 2009. Qualidade das águas interiores no Estado de São Paulo. São Paulo: CETESB. Série Relatórios.

CRUZ, C.D., REGAZZI, A.J. and CARNEIRO, P.C., 2012. Modelos biométricos aplicados ao melhoramento genético. Viçosa: Editora UFV, vol. 1, 514 p

FRANÇA, M.S., 2009. Análise estatística multivariada dos dados de monitoramento de qualidade de água da bacia do alto Iguaçu: uma ferramenta para a gestão de recursos hídricos. Curitiba: Universidade Federal do Paraná, 166 p. Masters Dissertation in Engineering of Water and Environmental Resources.

GUEDES, H.A.S., SILVA, D.D., ELESBON, A.A.A., RIBEIRO, C.B.M., MATOS, A.T. and SOARES, J.H.P., 2012. Aplicação da análise estatística multivariada no estudo da qualidade da água do Rio Pomba, MG. Revista Brasileira de Engenharia Agrícola e Ambiental, vol. 16 , no. 5, pp. 558-563.
HAAG, I. and WESTRICH, B., 2002. Processes governing river water quality identified by principal component analysis. Hydrological Processes, vol. 16, no. 16, pp. 3113-3130.

HELENA, B., PARDO, R., VEJA, M., BARRADO, E., FERNANDEZ, J.M. and FERNANDEZ, L., 2000. Temporal evolution of groundwater composition in an alluvial aquifer (Pisuerga river, Spain) by principal component analysis. Water Research, vol. 34, no. 3, pp. 807-816. http://dx.doi.org/10.1016/ S0043-1354(99)00225-0.

KUPPUSAMY, M.R. and GIRIDHAR, V.V., 2006. Factor analysis of water quality characteristics including trace metal speciation in the coastal environmental system of Chennai Ennore. Environment International, vol. 32, no. 2, pp. 174-179. http://dx.doi.org/10.1016/j.envint.2005.08.008. PMid:16214213.

LUZ, C.N., 2009. Uso e ocupação do solo e os impactos na qualidade dos recursos hídricos superficiais da bacia do rio Ipitanga. Salvador: Universidade Federal da Bahia. 131 p. Master's Dissertation in Urban Environmental Engineering.

MAGALHÃES JÚNIOR, A.P., 2000. A situação do monitoramento das águas no Brasil: instituições e iniciativas. Revista Brasileira de Recursos Hídricos, vol. 5, no. 3, pp. 113-115.

NAZIR, M.F., SAMSUDIN, M.S., MOHAMAD, S.I., AWALUDDIN, M.R.A., MANSOR, M.A., JUAHIR, H., RAMLI, J., 2011. River water quality modeling using combined Principle Component Analysis (PCA) and Multiple Linear Regressions (MLR): a case study at Klang River, Malaysia. World Applied Sciences Journal, vol. 14, pp. 73-82.

OUYANG, Y., 2005. Evaluation of river water quality monitoring stations by principal component analysis. Water Research, vol. 39, no. 12, pp. 2621-2635. http://dx.doi.org/10.1016/j. watres.2005.04.024. PMid:15993926.

REBOUÇAS, A.C., BRAGA, B. and TUNDISI, J.G., 1999. Águas Doces do Brasil:capital, uso e conservação. São Paulo: Escrituras Editora.

SIMEONOV, V., STRATIS, J.A., SAMARA, C., ZACHARIADIS, G., VOUTSA, D. and ANTHEMIDIS, A., SOFONIOU, M., KOUIMTZIS, T., 2003. Assessment of the surfacewater quality in Northern Greece. Water Research, vol. 37, p. 4119-4124.

SINGH, K.P., MALIK, A., MOHAN, D. and SINHA, S., 2004. Multivariate statistical techniques for the evaluation of spatial and temporal variations in water quality of Gomti River (India)-a case study. Water Research, vol. 38, no. 18, pp. 3980-3992. http:// dx.doi.org/10.1016/j.watres.2004.06.011. PMid:15380988.

VEGA, M., PARDO, R., BARRADO, E. and DEBAN, L., 1998. Assessment of seasonal and polluting effects on the quality of river water by exploratory data analysis. Water Research, vol. 32, no. 12, pp. 3581-3592. http://dx.doi.org/10.1016/S00431354(98)00138-9. 